\title{
Association between serum advanced oxidation protein products and mortality risk in maintenance hemodialysis patients
}

Chun Zhou ${ }^{1}$, Yuanyuan Zhang ${ }^{1}$, Jianghua Chen ${ }^{2}$, Changlin Mei ${ }^{3}$, Fei Xiong ${ }^{4}$, Wei Shi ${ }^{5}$, Wei Zhou ${ }^{6}$, Xusheng Liu' Shiren Sun ${ }^{8}$, Jianwei Tian ${ }^{1}$, Ziliang Ye ${ }^{1}$, Qimeng Wu ${ }^{1}$, Xianhui Qin ${ }^{1}$, Jianping Jiang ${ }^{1 *}$ and Fan Fan Hou ${ }^{1 *}$ on behalf of CCSD (China Collaborative Study on Dialysis) group

\begin{abstract}
Background: The association between serum advanced oxidation protein products (AOPP) and mortality risk remains equivocal. We aimed to assess the correlation of serum AOPP levels with the risk of all-cause mortality in hemodialysis (HD) patients.

Methods: A total of 1394 maintenance HD patients with complete data on AOPP and related parameters were included from China Collaborative Study on Dialysis (CCSD), a multi-center, prospective cohort study. The primary outcome was all-cause mortality, the secondary outcome was cardiovascular disease (CVD) mortality.

Results: During a median follow-up duration of 5.2 years (IQR, 2.1-5.4), all-cause mortality occurred in 492 (31.4\%) participants. Overall, there was a reversed L-shaped association between serum AOPP and all-cause mortality in HD patients ( $P$ for nonlinearity $=0.04$ ), with an inflection point at $87 \mu \mathrm{mol} / \mathrm{L}$. Accordingly, there was no significant association between serum AOPP and all-cause mortality (per SD increment; HR, 0.94; 95\% Cl, 0.84, 1.05) in participants with $\mathrm{AOPP}<87 \mu \mathrm{mol} / \mathrm{L}$. However, there was a positive relationship of serum AOPP and all-cause mortality (per SD increment; $H R, 1.24 ; 95 \% C l, 1.08,1.42)$ in those with $A O P P \geq 87 \mu \mathrm{mol} / \mathrm{L}$. Moreover, a similar trend was found for CVD mortality.
\end{abstract}

Conclusions: Elevated serum AOPP levels were associated with higher risk of all-cause mortality in Chinese maintenance HD patients.

Keywords: Advanced oxidation protein products, All-cause mortality, Cardiovascular mortality, Hemodialysis patients

*Correspondence: jiangjp_nfyy@126.com; ffhouguangzhou@163.com ${ }^{1}$ Division of Nephrology, National Clinical Research Center for Kidney Disease, State Key Laboratory of Organ Failure Research, Guangdong Provincial Key Laboratory of Renal Failure Research, Guangzhou Regenerative Medicine and Health Guangdong Laboratory, Guangdong Provincial Clinical Research Center for Kidney Disease, Nanfang Hospital, Southern Medical University, Guangdong Provincial Institute of Nephrology, Guangzhou 510515, China

Full list of author information is available at the end of the article

\section{Introduction}

Hemodialysis (HD) is a life-sustaining treatment for patients with end-stage kidney disease (ESKD). HD patients usually have a substantially increased risk of all-cause and cardiovascular disease (CVD) mortality $[1,2]$. Since traditional risk factors could not account for all mortality risks in HD patients, it is of great clinical importance to identify more modifiable risk factors to reduce the mortality burden in HD patients.

Recently, a growing body of evidence suggested that $\mathrm{HD}$ is characterized by oxidative stress resulting from

(c) The Author(s) 2021. This article is licensed under a Creative Commons Attribution 4.0 International License, which permits use, sharing, adaptation, distribution and reproduction in any medium or format, as long as you give appropriate credit to the original author(s) and the source, provide a link to the Creative Commons licence, and indicate if changes were made. The images or other third party material in this article are included in the article's Creative Commons licence, unless indicated otherwise in a credit line to the material. If material is not included in the article's Creative Commons licence and your intended use is not permitted by statutory regulation or exceeds the permitted use, you will need to obtain permission directly from the copyright holder. To view a copy of this licence, visit http://creativeco mmons.org/licenses/by/4.0/. The Creative Commons Public Domain Dedication waiver (http://creativecommons.org/publicdomain/ zero/1.0/) applies to the data made available in this article, unless otherwise stated in a credit line to the data. 
loss of antioxidants and accumulation of oxidative products during dialysis procedures [3-6]. Advanced oxidation protein products (AOPP), which result from the interaction between oxidants and plasma proteins, are considered reliable markers to estimate the degree of oxidant-mediated protein damage [7, 8]. Plasma levels of AOPP were higher in patients on hemodialysis, than those on peritoneal dialysis and general population [7]. However, few studies have reported the association between AOPP and the risk of mortality with inconsistent results and have not assessed AOPP continuously [9, 10]. Furthermore, the possible modifiers on the correlation of AOPP and mortality risk have not been evaluated in these studies.

Using data from China Collaborative Study on Dialysis (CCSD), a large scale, multi-center, prospective cohort study, we investigated the association of serum AOPP with all-cause, and CVD mortality, and examined the modifiers for the association in patients undergoing HD.

\section{Methods}

\section{Participants and design}

The baseline data of CCSD has been reported elsewhere [11-14]. In summary, CCSD is a multi-center study, performed in 9 large dialysis facilities (at least $200 \mathrm{HD}$ patients in each facility) in 6 cities of China (Beijing, Shanghai, Guangzhou, Hangzhou, Wuhan, and Xi'an). Eligible participants were men and women aged $\geq 18$ years, and with ESKD undergoing dialysis between January 1, 2005, and December 1, 2010. Excluded patients were those with uncompleted data or dialysis duration less than 3 months. The current cohort study enrolled 1,567 eligible HD participants from the CCSD, followed from July, 2010 to February, 2016 (Additional file 1: Figure S1). This study was approved by the local ethics committee in each center, and all participants provided written informed consent.

\section{Data collection, measurements, and follow-up}

Baseline data of the present study were derived from the database of CCSD. All data were collected at enrollment on the basis of review of medical records by two experienced doctors and dialysis research nurses. The data, including demographic data, underlying renal diseases, medication records, dialysis modality, dialysis program, and cardiovascular morbidity, which was defined as the presence of clinically diagnosed ischemic heart disease, heart failure, and/or stroke after initiation of dialysis, were collected.

Blood pressure measurement was taken by sphygmomanometer before each of the three HD sessions, three times at $1 \mathrm{~min}$ intervals, all after $10 \mathrm{~min}$ of rest in a supine decubitus position. The mean of the three readings was calculated [15].

Participants were scheduled for follow-up every 1-3 months in each center. At each follow-up visit, possible endpoint events were documented by trained research staff and physicians.

\section{Hemodialysis regimens}

Participants were dialyzed twice or thrice weekly with low-flux polysulphone or polyacrylamide dialyzer, either 1.5 or $1.7 \mathrm{~m}^{2}$ (Fresenius, Germany; Gambro, Sweden; Nipro, Japan; B. Braun, Germany; Langsheng, China). All treatments were of $4 \mathrm{~h}$ to $5 \mathrm{~h}$ duration with conventional glucose-free, bicarbonate-based dialysate containing $1.25-1.5 \mathrm{mM}$ calcium, $2.0 \mathrm{mM}$ potassium and $138 \mathrm{mM}$ sodium. Dialysate flow was $500 \mathrm{~mL} / \mathrm{min}$.

\section{Laboratory assays}

Baseline fasting venous serum specimens were collected before the hemodialysis sessions. Biochemical tests were performed by the clinical laboratories in individual local dialysis facilities, using automatic clinical analyzers following the same standard protocol.

Measurement of serum AOPP was performed in the central laboratory based on a spectrophotometric detection as previously described [11]. To avoid the confounding effect of endogenous compounds such as triglyceride on measurement, fasting serum samples were collected, centrifuged, stored in aliquots with delipidating procedures without repeat frozen and thaw [16-18]. For measurement, $10 \mathrm{~mL}$ of serum diluted 1:10 with phosphate-buffered saline (PBS), $200 \mathrm{~mL}$ of chloramine $\mathrm{T}$ $(0-100 \mathrm{~mol} / \mathrm{L})$ for calibration and $200 \mathrm{~mL}$ of PBS as blank were applied on a microlitre plate. Ten microlitres of $1.16 \mathrm{M}$ potassium iodide and $10 \mathrm{~mL}$ of acetic acid were added and absorbance at $340 \mathrm{~nm}$ was measured immediately. Concentration of AOPP is expressed in micromoles per litre $(\mu \mathrm{mol} / \mathrm{L})$ of chloramines-T equivalent. The coefficients of intra- and inter-assay variations were $1.95 \%$ and $3.7 \%$, respectively.

\section{Study outcomes}

All-cause mortality was the primary outcome, which included death due to any reason. The secondary outcome was CVD mortality, which included sudden cardiac death, stroke, myocardial infarction (MI), heart failure, and death due to other known vascular causes. Evidence for death included death certificates from hospitals or reports from investigator visits.

\section{Statistical analysis}

Baseline characteristics are presented as the mean \pm standard deviations (SDs) or median 
(interquartile range) for continuous variables and proportions for categorical variables, respectively. Differences in population characteristics according to categories $(<87$ versus $\geq 87 \mu \mathrm{mol} / \mathrm{L}$ ) of baseline AOPP were compared using $t$ test, Wilcoxon rank sum test, or Chi-squared tests, accordingly.

There were missing values on hemoglobin $(\mathrm{n}=30)$, white blood cell $(n=30)$, calcium $(n=36)$, phosphate $(\mathrm{n}=44)$ at baseline. Multiple imputations were used to handle missing values at baseline in the outcome analyses. The association between serum AOPP and all-cause mortality and CVD mortality were estimated using Cox proportional hazard regression models, without and with adjustments for age, sex, body mass index (BMI), smoking, dialysis vintage, hemoglobin, phosphate, iron supplementation, use of phosphorus binder, study center, CVD status, hypertension status and diabetes status at baseline. The proportional hazards' assumption was checked using statistical tests based on the scaled Schoenfeld residuals. We first conducted restricted cubic spline (RCS) Cox regression, with 4 knots (20th, 40th, 60th, 80th percentiles of AOPP), to test for linearity and explore the shape of serum AOPP with all-cause mortality and CVD mortality. We then used segmented regression that is using a separate line segment to fit each interval. Loglikelihood ratio test comparing one-line (non-segmented) model to segmented regression model was used to determine whether threshold exists. The inflection points that connecting the segments was based on the model gives maximum likelihood, and it was determined using two steps recursive method. The detailed information for the determination of thresholds was shown in the supplemental file. Additionally, possible effect modifiers on the association between serum AOPP and all-cause mortality were evaluated by stratified analyses and interaction testing, using likelihood ratio test.

Two-tailed $P<0.05$ was considered statistically significant in all analyses. All statistical analyses were performed using R software, version 4.0.1 (http://www.Rproject.org/, accessed June 6, 2020).

\section{Results}

\section{Characteristics of participants}

As shown in the flow chart (Additional file 1: Figure S1), 1,835 participants were in the follow-up study. Of those, a total of 1,567 HD patients with complete data on AOPP at baseline, were included in the final analysis. During the follow up, patients with kidney transplant $(\mathrm{N}=183)$, transfer to peritoneal dialysis $(\mathrm{N}=17)$, or lost to followup $(\mathrm{N}=1)$, were censored.

Baseline demographic, clinical and laboratory characteristics of the included patients by categories of baseline serum AOPP were illustrated in Table 1. The
Table 1 Baseline characteristics of the participants by serum AOPP categories

\begin{tabular}{|c|c|c|c|}
\hline \multirow[t]{2}{*}{ Variables } & \multicolumn{2}{|c|}{ Baseline serum AOPP, $\mu \mathrm{mol} / \mathrm{L}$} & \multirow[t]{2}{*}{$P$-value } \\
\hline & $<87$ & $\geq 87$ & \\
\hline N & 1126 & 441 & \\
\hline Male, no. (\%) & $649(57.6)$ & $247(56.0)$ & 0.558 \\
\hline Age, year & $55.0 \pm 15.6$ & $58.4 \pm 14.2$ & $<0.001$ \\
\hline $\begin{array}{l}\text { Dialysis vintage, } \\
\text { month }\end{array}$ & $28.9(11.8-60.5)$ & $35.1(18.6-67.9)$ & $<0.001$ \\
\hline $\mathrm{BMI}, \mathrm{kg} / \mathrm{m}^{2}$ & $21.3 \pm 3.3$ & $22.2 \pm 3.7$ & $<0.001$ \\
\hline MAP, mmHg & $103.1 \pm 14.0$ & $101.6 \pm 14.3$ & 0.055 \\
\hline Smoking, no. (\%) & $134(11.9)$ & $66(15.0)$ & 0.102 \\
\hline CVD, no. (\%) & $562(49.9)$ & $241(54.6)$ & 0.092 \\
\hline Diabetes, no. (\%) & $557(49.5)$ & $262(59.4)$ & $<0.001$ \\
\hline Hypertension, no. (\%) & $1028(91.3)$ & $410(93.0)$ & 0.278 \\
\hline \multicolumn{4}{|l|}{ Laboratory results } \\
\hline $\begin{array}{l}\text { C-reactive protein, } \\
\text { mg/L }\end{array}$ & $3.4(1.8-10.3)$ & $4.7(2.9-10.3)$ & 0.011 \\
\hline Albumin, g/L & $39.7 \pm 6.3$ & $39.6 \pm 6.8$ & 0.886 \\
\hline Hemoglobin, g/L & $102.4 \pm 20.5$ & $105.4 \pm 18.7$ & 0.008 \\
\hline $\begin{array}{l}\text { White blood cells, } \\
10^{9} / \mathrm{L}\end{array}$ & $5.9 \pm 1.9$ & $6.2 \pm 2.0$ & 0.009 \\
\hline Calcium, mmol/L & $2.2 \pm 0.3$ & $2.3 \pm 0.3$ & 0.055 \\
\hline Phosphate, mmol/L & $1.9 \pm 0.7$ & $2.1 \pm 0.7$ & $<0.001$ \\
\hline iPTH, pg/mL & $258(131.2-500.3)$ & $280.7(138.5-608.9)$ & 0.147 \\
\hline $\begin{array}{l}\text { Total choles- } \\
\text { terol, mmol/L }\end{array}$ & $4.0 \pm 1.0$ & $4.4 \pm 1.2$ & $<0.001$ \\
\hline $\mathrm{TG}, \mathrm{mmol} / \mathrm{L}$ & $1.1(0.8-1.6)$ & $1.8(1.1-2.7)$ & $<0.001$ \\
\hline AOPP, $\mu \mathrm{mol} / \mathrm{L}$ & $68 \pm 11$ & $105 \pm 19$ & $<0.001$ \\
\hline \multicolumn{4}{|l|}{$\begin{array}{l}\text { Medication use, no. } \\
(\%)\end{array}$} \\
\hline ACEI/ARB & $564(50.1)$ & $214(48.5)$ & 0.578 \\
\hline $\begin{array}{l}\text { Glucose-lowering } \\
\text { drugs }\end{array}$ & $135(12.0)$ & $85(19.3)$ & $<0.001$ \\
\hline $\begin{array}{l}\text { Lipid-lowering } \\
\text { drugs }\end{array}$ & $98(8.7)$ & $42(9.5)$ & 0.609 \\
\hline Antiplatelet drugs & $146(13.0)$ & $51(11.6)$ & 0.452 \\
\hline Iron supplement & $598(53.1)$ & $219(49.7)$ & 0.219 \\
\hline Phosphorus binder & $439(39.0)$ & $205(46.5)$ & 0.007 \\
\hline
\end{tabular}

Continuous variables are presented as Mean \pm SDs or median (interquartile range), categorical variables are presented as no. (\%)

$B M I$ body mass index, MAP mean arterial pressure, CVD cardiovascular disease, IPTH parathyroid hormone, TG triglyceride, AOPP advanced oxidation protein products

mean age of the patients was $55.9 \pm 15.3$ years old, $57.2 \%$ of the patients were males, and the median dialysis duration was 30.8 months with interquartile range of 13.7 to 63.5 months. The mean serum AOPP level was $78 \pm 22 \mu \mathrm{mol} / \mathrm{L}$. Patients with higher AOPP levels were more likely to be older, had longer duration of dialysis, higher BMI, C-reactive protein, hemoglobin, white blood cells, phosphate, total cholesterol, and 
TG levels. In addition, patients with higher AOPP levels had a higher frequency of using glucose-lowering drugs, phosphorus binder and a higher prevalence of diabetes at baseline.

Furthermore, in the multiple regression models, smoking status, dialysis vintage, phosphate, total cholesterol, and TG were significantly associated with serum AOPP (Additional file 1: Table S1).

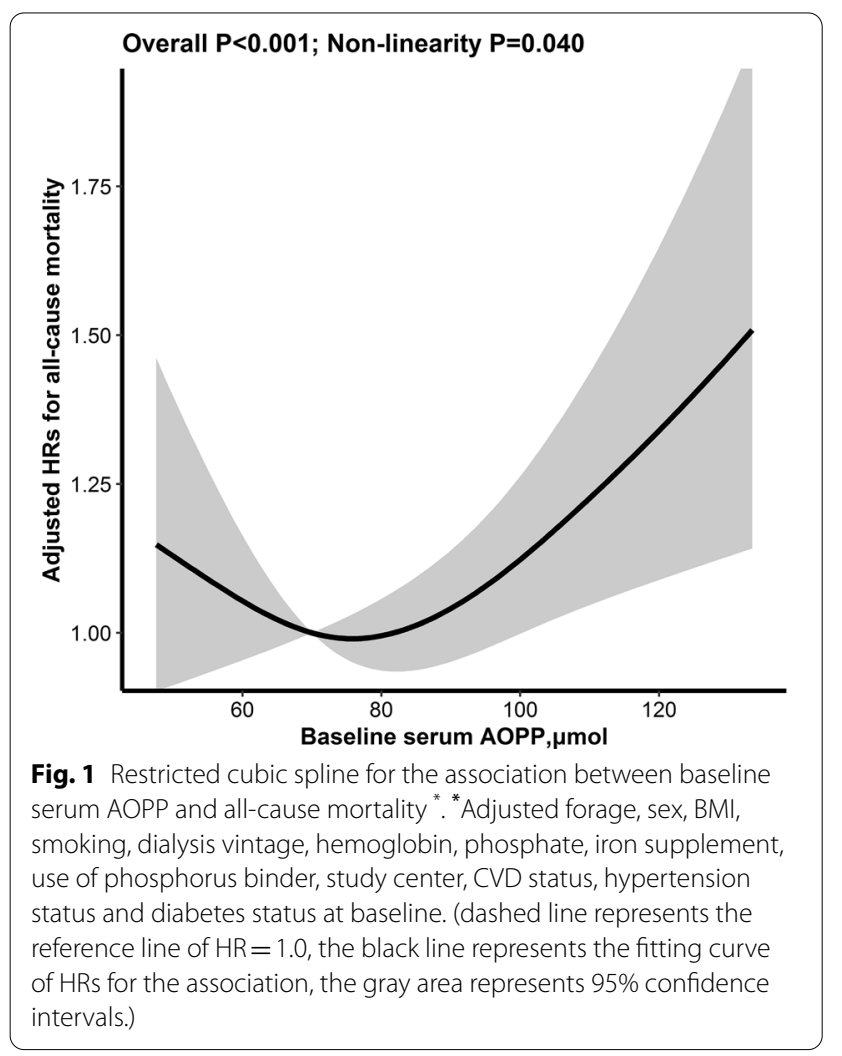

\section{Association between AOPP and study outcomes}

During a median follow-up duration of 5.2 years (IQR, 2.1-5.4), all-cause or CVD mortality occurred in 492 (31.4\%) and 340 (21.7\%) participants, respectively.

Serum AOPP levels were significantly higher in the mortality group compared with the survival group (mean \pm SDs, $81 \pm 25$ vs. $77 \pm 20 \mu \mathrm{mol} / \mathrm{L}, \quad P<0.001$ ). Overall, there was a reversed L-shaped association between serum AOPP and all-cause mortality in HD patients $(P$ for nonlinearity $=0.04)$, with an inflection point at $87 \mu \mathrm{mol} / \mathrm{L}$. (Fig. 1). There was no significant association between serum AOPP and all-cause mortality (per SD increment; HR, 0.94; 95\%CI, 0.84, 1.05) in participants with AOPP $<87 \mu \mathrm{mol} / \mathrm{L}$. However, there was a positive relationship of serum AOPP and all-cause mortality (per SD increment; HR, 1.24; 95\%CI, 1.08, 1.42) in those with AOPP $\geq 87 \mu \mathrm{mol} / \mathrm{L}$ (Table 2). As expected, compared with those with $\mathrm{AOPP}<87 \mu \mathrm{mol} / \mathrm{L}$, a significantly higher risk of all-cause mortality was found in participants with AOPP $\geq 87 \mu \mathrm{mol} / \mathrm{L}$ (HR, 1.23 ; 95\%CI: 1.02 , 1.48; Additional file 1: Figure S3A). In the Cox proportional hazard regression models, no clear evidence was found against the proportional hazards' assumption in the model (All $P$ values $>0.05$ ). Moreover, a similar trend was found with further adjustments for total cholesterol, TG, albumin, PTH, KT/V, and the use of EPO at baseline (Additional file 1: Table S2). Of note, the association between AOPP and all-cause mortality remained significant after Bonferroni multiple test correction for two tests (adjusted $P=0.025$ ).

A similar trend was found for the CVD mortality, with an inflection point at $88 \mu \mathrm{mol} / \mathrm{L}$ (Table 2, Additional file 1: Figures S2, S3B).

\section{Stratified analyses by potential effect modifiers}

Among participants with AOPP $\geq 87 \mu \mathrm{mol} / \mathrm{L}$, we further performed stratified analyses to assess the association

Table 2 Threshold effect analyses of serum AOPP (per SD increment) on all-cause mortality and CVD mortality using two-piecewise regression models

\begin{tabular}{|c|c|c|c|c|c|c|}
\hline \multirow[t]{2}{*}{ AOPP, $\mu \mathrm{mol} / \mathrm{L}$} & \multirow[t]{2}{*}{ Case } & \multirow[t]{2}{*}{ Incident rate (\%) } & \multicolumn{2}{|c|}{ Unadjusted model } & \multicolumn{2}{|c|}{ Adjusted model* } \\
\hline & & & $\mathrm{HR}(95 \% \mathrm{Cl})$ & $P$ value & $\mathrm{HR}(95 \% \mathrm{Cl})$ & $P$ value \\
\hline \multicolumn{7}{|c|}{ All-cause mortality } \\
\hline$<87$ & 332 & 29.5 & $0.97(0.87,1.08)$ & 0.561 & $0.94(0.84,1.05)$ & 0.295 \\
\hline$\geq 87$ & 160 & 36.3 & $1.25(1.10,1.43)$ & $<0.001$ & $1.24(1.08,1.42)$ & $0.002^{\mathrm{a}}$ \\
\hline \multicolumn{7}{|l|}{ CVD mortality } \\
\hline$<88$ & 242 & 21.0 & $0.95(0.84,1.08)$ & 0.421 & $0.89(0.78,1.01)$ & 0.068 \\
\hline$\geq 88$ & 98 & 23.7 & $1.19(1.00,1.42)$ & 0.046 & $1.26(1.05,1.52)$ & 0.015 \\
\hline
\end{tabular}

*Adjusted for age, sex, BMI, smoking, dialysis vintage, hemoglobin, phosphate, iron supplement, use of phosphorus binder, study centers, CVD status, hypertension status and diabetes status at baseline

${ }^{\text {a }}$ For the primary outcome (all-cause mortality), since there are two times assessments, we used the Bonferroni method and accepted $P<0.025$ as significant 


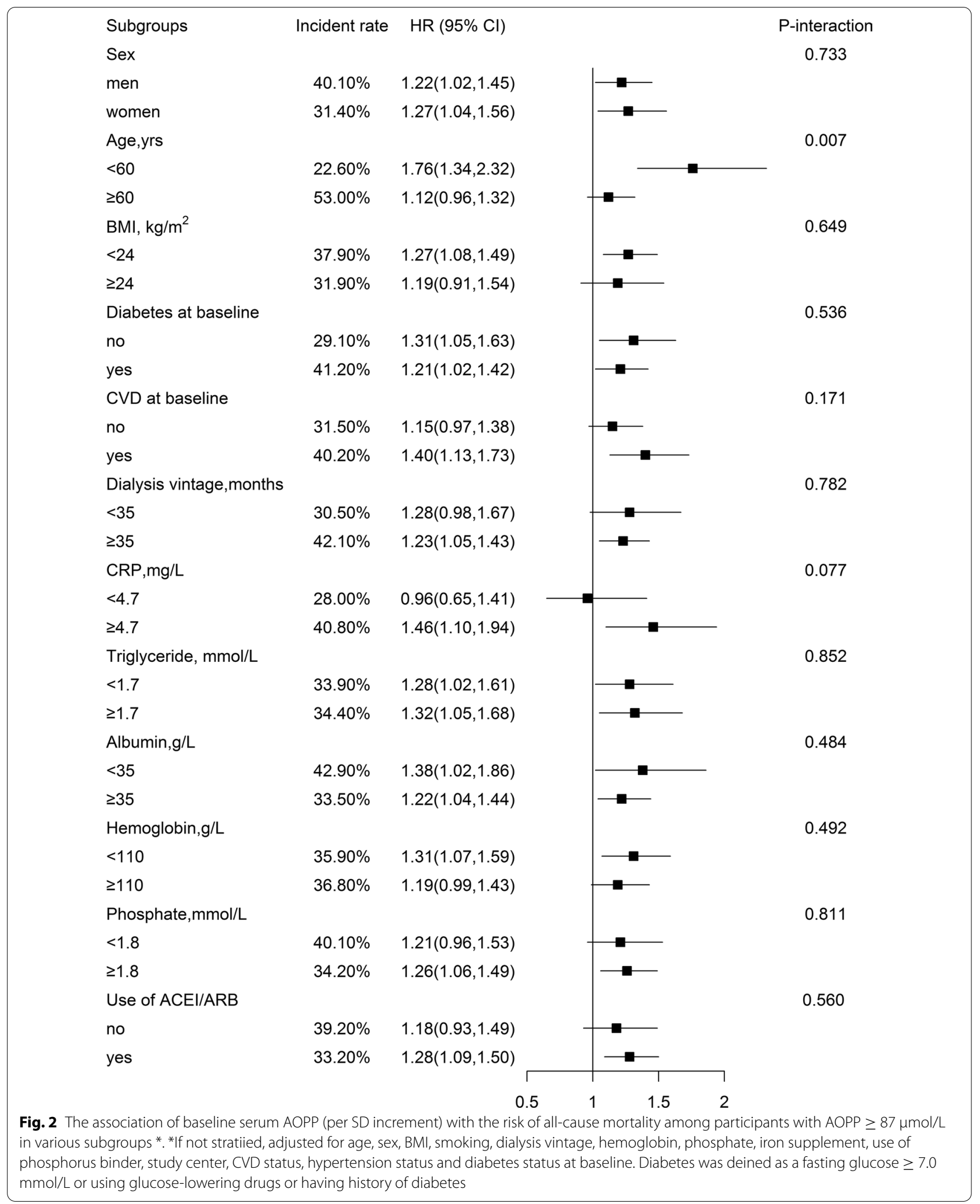


between baseline AOPP levels (per SD increment) and risk of all-cause mortality in various subgroups (Fig. 2). A stronger association between AOPP levels and allcause mortality was found in HD patients with younger age (<60 years, adjusted HR, 1.76; 95\%CI: 1.34, 2.32 $v s . \geq 60$ years, adjusted $\mathrm{HR}, 1.12$; $95 \% \mathrm{CI}: 0.96,1.32$; $P$-interaction $=0.007$ ).

None of other factors significantly modified the association between AOPP levels and risk of all-cause mortality in HD patients (all $P$-interactions $>0.05$ ) (Fig. 2).

\section{Discussion}

The present study first demonstrated that elevated baseline AOPP levels was significantly associated with higher risk of all-cause mortality in Chinese maintenance hemodialysis (MHD) patients. Moreover, a stronger association between AOPP and all-cause mortality was found in non-diabetic HD patients.

Few previous studies have been conducted to investigate the relation of AOPP with mortality, and the reported results have been inconsistent. One reported a positive link between AOPP levels and mortality risk in 540 non-HD, Brazilian elders [9]. However, another conducted in 112 HD patients, found that AOPP had no significant impact on survival in relatively young Brazilian HD patients [10]. Of note, due to the low sample size of the previous studies, the possible effect modifies for the AOPP-mortality association had not been fully examined in previous studies $[9,10]$. Moreover, these two studies only assessed the association between AOPP and mortality by using AOPP as dichotomous variables (median, or $\leq 60$ versus $>60 \mu \mathrm{mol} / \mathrm{L}$ ), and did not allow for the possibility of non-linear association between AOPP and mortality. These results indicated that the association between AOPP and mortality risk remains inconclusive.

Our study provided an opportunity to evaluate the dose-response association between AOPP levels and the risk of mortality in HD patients with by far the largest sample size in any similar studies, and included a comprehensive adjustment and stratified analysis for a series of important confounders. Our study provided some new insights. First, there was a reversed L-shaped association serum AOPP and all-cause mortality in HD patients, with an inflection point at $87 \mu \mathrm{mol} / \mathrm{L}$. That is to say that there was a threshold of serum AOPP level at about $87 \mu \mathrm{mol} / \mathrm{L}$, above which the risk of all-cause mortality increased. In fact, some biological plausibility of the positive association between AOPP and mortality has been reported. MHD patients were reported to have imbalances between pro-inflammatory cytokines and their inhibitors, and between oxidants and antioxidants defense, resulting in a state of overwhelmed chronic oxidative stress [19-24]. Excess reactive oxygen species could induce damage to proteins, indicated by increased AOPP levels. Damaged proteins, could change enzyme levels and susceptibility to proteolytic, result in less active intracellular status, thereby contribute to structural and functional detriment of cells [25-28]. Moreover, oxidant-mediated protein damage may injure the anti-oxidant activity of albumin, and lead to the oxidative burst and synthesis of pro-inflammatory and inflammatory cytokines in human neutrophils and monocytes, then increase the accumulation of oxidants and inflammation [29]. Damaged cells along with oxidants and inflammation will accelerate atherosclerosis [30-32], which is closely related to coronary artery diseases [33], metabolic syndrome [34], and cancers [35-37], all might account for accumulating risk of mortality. However, more studies are warranted to confirm our findings and to further investigate the underlying mechanisms involved in the association between AOPP and mortality.

Second, among participants with AOPP $\geq 87 \mu \mathrm{mol} / \mathrm{L}$, the stronger association of AOPP with all-cause mortality was found in younger MHD patients. It had been reported that aging was associated with an increase of cellular senescence and reactive oxygen species, which leads to oxidation, inflammation, and cell membrane [38]. A recent study further suggested that aging is a product of oxidative damage to mitochondrial DNA [39]. As expected, in our current study, older patients had significantly increased mortality risk. As such, we speculated that the high level of oxidative stress in older patients may possibly attenuate the positive association between higher AOPP and the risk of mortality. However, further studies are needed to verify this hypothesis and further investigate the underlying mechanisms.

Several shortcomings of the present study are needed to be considered. First, though a broad series of covariates were adjusted in the regression model, unmeasured or unknown residual confounding have not been fully considered. Second, the serum AOPP was only assessed once at baseline, thus the variability of AOPP during follow-up has not been taken into account. Third, we have not available data on antioxidant and antioxidant enzymes concentration. Therefore, we could not examine the association between antioxidant levels and AOPP, and evaluate whether theses variables may affect the relationship of AOPP with mortality risk. Fourth, the present study was conducted in Chinese hemodialysis patients, generalizability of the results to other ethnic or countries is still in need of consideration. As such, our findings should be further confirmed in more studies.

In conclusion, our study suggested that elevated serum AOPP levels were associated with higher risk of all-cause mortality in MHD patients. Our findings, if further 
confirmed, are highly relevant to clinical practice, in terms of early detection of the mortality risk in MHD patients.

\begin{abstract}
Abbreviations
AOPP: Advanced oxidation protein products; HD: Hemodialysis; MHD: Maintenance hemodialysis; CCSD: China Collaborative Study on Dialysis; CVD: Cardiovascular disease; ESKD: End-stage kidney disease; PBS: Phosphate-buffered saline; MI: Myocardial infarction; SDs: Standard deviations; BMI: Body mass index; HDL-C: High-density lipoprotein cholesterol; MBP: Mean blood pressure; CRP: C-reactive protein; iPTH: Parathyroid hormone; TG: Triglyceride.
\end{abstract}

\section{Supplementary Information}

The online version contains supplementary material available at https://doi. org/10.1186/s12967-021-02960-w.

Additional file 1. Additional figures and tables.

\section{Acknowledgements}

Not applicable.

\section{Authors' contributions}

$J J$, FFH and CCSD investigators, designed the study; JJ, FFH and CCSD investigators, conducted the study; $C Z$, JJ, and XQ analyzed the data; CZ, JJ, and XQ drafted of the manuscript. All authors read and approved the final manuscript.

\section{Funding}

This study was funded by the National Natural Science Foundation of China (82070790 to J.P.J), the Nature Science Foundation of Guangdong Province (2014A030313345 to J.P. J), the Clinical Innovation Research Program of Guangzhou Regenerative Medicine and Health Guangdong Laboratory (2018GZR0201003 to F.F.H.), the Research Fund Program of Guangdong Provincial Key Laboratory of Renal Failure Research (2017B030314036 to F.F.H.), the Major International (Regional) Joint Research Project (81620108003 to F.F.H.), and the National Innovation Team Program (81521003 to Y.H.L).

\section{Availability of data and materials}

Not applicable.

\section{Declarations}

\section{Ethics approval and consent to participate}

This study was approved by the local ethics committee in each center, and all participants provided written informed consent.

\section{Consent for publication}

Not applicable.

\section{Competing interests}

The authors declare that they have no competing interests.

\section{Author details}

'Division of Nephrology, National Clinical Research Center for Kidney Disease, State Key Laboratory of Organ Failure Research, Guangdong Provincial Key Laboratory of Renal Failure Research, Guangzhou Regenerative Medicine and Health Guangdong Laboratory, Guangdong Provincial Clinical Research Center for Kidney Disease, Nanfang Hospital, Southern Medical University, Guangdong Provincial Institute of Nephrology, Guangzhou 510515, China. ${ }^{2}$ Kidney Disease Center, College of Medicine, The First Affiliated Hospital, Zhejiang University, Hangzhou, China. ${ }^{3}$ Division of Nephrology, Changzheng Hospital, Shanghai, China. ${ }^{4}$ Department of Nephrology, Wuhan No. 1 Hospital, Tongji Medical College, Huazhong University of Science and Technology, Wuhan, China. ${ }^{5}$ Department of Nephrology, Guangdong Provincial People's Hospital, Guangdong Academy of Medical Sciences, Guangzhou, China. ${ }^{6}$ Department of Nephrology, The 8th Medical Center of Chinese, PLA General
Hospital, Beijing, China. ${ }^{7}$ Departmentof Nephrology, Guangdong Provincial Hospital of Chinese Medicine (The Second Affiliated Hospital of Guangzhou University of Chinese Medicine), Guangzhou, China. ${ }^{8}$ Department of Nephrology, Xijing Hospital, Xi'an, China.

Received: 9 March 2021 Accepted: 23 June 2021

Published online: 30 June 2021

\section{References}

1. GBD 2017 Causes of Death Collaborators. Global, regional, and national age-sex-specific mortality for 282 causes of death in 195 countries and territories, 1980-2017: a systematic analysis for the Global Burden of Disease Study 2017. Lancet. 2018;392(10159):1736-88. https://doi.org/10. 1016/S0140-6736(18)32203-7.

2. Levey AS, Schoolwerth AC, Burrows NR, Williams DE, Stith KR, McClelIan W, et al. Comprehensive public health strategies for preventing the development, progression, and complications of CKD: report of an expert panel convened by the Centers for Disease Control and Prevention. Am J Kidney Dis. 2009;53:3. https://doi.org/10.1053/j.ajkd.2008.11.019.

3. Locatelli F, Canaud B, Eckardt KU, Stenvinkel P, Wanner C, Zoccali C. Oxidative stress in end-stage renal disease: an emerging threat to patient outcome. Nephrol Dial Transplant. 2003;18(7):1272-80. https://doi.org/10. 1093/ndt/gfg074.

4. Liakopoulos V, Roumeliotis S, Gorny X, Dounousi E, Mertens PR. Oxidative stress in hemodialysis patients: a review of the literature. Oxid Med Cell Longev. 2017;2017:3081856. https://doi.org/10.1155/2017/3081856.

5. Bellia C, Cosma C, Lo Sasso B, Bivona G, Agnello L, Zaninotto M, Ciaccio M. Glycated albumin as a glycaemic marker in patients with advanced chronic kidney disease and anaemia: a preliminary report. Scand J Clin Lab Invest. 2019;79(5):293-7. https://doi.org/10.1080/00365513.2019. 1613673

6. Bellia C, Zaninotto M, Cosma C, Agnello L, Bivona G, Marinova M, et al. Clinical usefulness of Glycated Albumin in the diagnosis of diabetes: Results from an Italian study. Clin Biochem. 2018;54:68-72. https://doi. org/10.1016/j.clinbiochem.2018.02.017.

7. Witko-Sarsat V, Friedlander M, Capeillère-Blandin C, Nguyen-Khoa T, Nguyen AT, Zingraff J, et al. Advanced oxidation protein products as a novel marker of oxidative stress in uremia. Kidney Int. 1996;49(5):1304-13. https://doi.org/10.1038/ki.1996.186.

8. Cao W, Hou FF, Nie J. AOPPs and the progression of kidney disease. Kidney Int Suppl. 2011;4(1):102-6. https://doi.org/10.1038/kisup.2014.19.

9. Silva TO, Jung IE, Moresco RN, Barbisan F, Ribeiro EE, Ribeiro EA, et al. Association between advanced oxidation protein products and 5-year mortality risk among amazon riparian elderly population. Free Radic Res. 2015;49(2):204-9. https://doi.org/10.3109/10715762.2014.992895.

10. Pachaly MA, do Nascimento MM, Suliman ME, Hayashi SY, Riella MC, Manfro RC, et al. Interleukin- 6 is a better predictor of mortality as compared to C-reactive protein, homocysteine, pentosidine and advanced oxidation protein products in hemodialysis patients. Blood Purif 2008; 26(2):204210, https://doi.org/10.1159/000117438.

11. Zhou Q, Wu S, Jiang J, Tian J, Chen J, Yu X, et al. Accumulation of circulating advanced oxidation protein products is an independent risk factor for ischaemic heart disease in maintenance haemodialysis patients. Nephrology (Carlton). 2012;17(7):642-9. https://doi.org/10.1111/j.1440-1797.2012. 01640.x.

12. Jiang J, Chen P, Chen J, Yu X, Xie D, Mei C, et al. Accumulation of tissue advanced glycation end products correlated with glucose exposure dose and associated with cardiovascular morbidity in patients on peritoneal dialysis. Atherosclerosis. 2012;224:187-94. https://doi.org/10.1016/j.ather osclerosis.2012.06.022.

13. Hou F, Jiang J, Chen J, Yu X, Zhou Q, Chen P, et al. China collaborative study on dialysis: a multi-centers cohort study on cardiovascular diseases in patients on maintenance dialysis. BMC Nephrol. 2012;13:94. https://doi. org/10.1186/1471-2369-13-94.

14. Zhou QG, Jiang JP, Wu SJ, Tian JW, Chen JH, et al. Current pattern of Chinese dialysis units: a cohort study in a representative sample of units. Chin Med J (Engl). 2012;125:3434-9.

15. Chinese guidelines for the management of hypertension. Zhongguo Gao Xue Ya Za Zhi. 2006;08:575-82. 
16. Chen $Y H$, Shi W, Liang XL, Liang YZ, Fu X. Effect of blood sample type on the measurement of advanced oxidation protein products as a biomarker of inflammation and oxidative stress in hemodialysis patients. Biomarkers. 2011;16(2):129-35. https://doi.org/10.3109/1354750X.2010.535172.

17. Valli A, Suliman ME, Meert N, Vanholder R, Lindholm B, Stenvinkel P, et al. Overestimation of advanced oxidation protein products in uremic plasma due to presence of triglycerides and other endogenous factors. Clin Chim Acta. 2007;379:87-94. https://doi.org/10.1016/j.cca.2006.12.026.

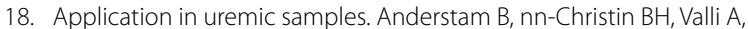
Stenvinkel P, Lindholm B, Suliman ME. Modification of the oxidative stress biomarker AOPP assay. Clin Chim Acta. 2008;393:114-8. https://doi.org/ 10.1016/j.cca.2008.03.029

19. Pereira BJ, Shapiro L, King AJ, Falagas ME, Strom JA, Dinarello CA. Plasma levels of IL-1 beta, TNF alpha and their specific inhibitors in undialyzed chronic renal failure CAPD and hemodialysis patients. Kidney Int. 1994:45(3):890-6. https://doi.org/10.1038/ki.1994.117.

20. Descamps-Latscha B, Herbelin A, Nguyen AT, Roux-Lombard P, Zingraff J, Moynot A, et al. Balance between IL-1 beta, TNF-alpha, and their specific inhibitors in chronic renal failure and maintenance dialysis Relationships with activation markers of T cells, B cells, and monocytes. J Immunol. 1995;154(2):882-92

21. Canaud B, Cristol J, Morena M, Leray-Moragues H, BosC J, Vaussenat F. Imbalance of oxidants and antioxidants in haemodialysis patients. Blood Purif. 1999;17(2-3):99-106. https://doi.org/10.1159/000014381.

22. Nguyen AT, Lethias C, Zingraff J, Herbelin A, Naret C, Descamps-Latscha B. Hemodialysis membrane-induced activation of phagocyte oxidative metabolism detected in vivo and in vitro within microamounts of whole blood. Kidney Int. 1985;28(2):158-67. https://doi.org/10.1038/ki.1985.136.

23. Himmelfarb J, Lazarus JM, Hakim R. Reactive oxygen species production by monocytes and polymorphonuclear leukocytes during dialysis. Am J Kidney Dis. 1991;17(3):271-6. https://doi.org/10.1016/s0272-6386(12) 80473-2.

24. Witko-Sarsat V, Nguyen-Khoa T, Jungers P, Drüeke TB, Descamps-Latscha B. Advanced oxidation protein products as a novel molecular basis of oxidative stress in uraemia. Nephrol Dial Transplant. 1999;14(Suppl 1):76-8. https://doi.org/10.1093/ndt/14.suppl_1.76.

25. Stadtman ER. Metal ion-catalyzed oxidation of proteins: biochemical mechanism and biological consequences. Free Radic Biol Med. 1990;9:4 https://doi.org/10.1016/0891-5849(90)90006-5.

26. Davies KJ, Lin SW, Pacifici RE. Protein damage and degradation by oxygen radicals. IV. Degradation of denatured protein. J Biol Chem. 1987;262(20):9914-20

27. Agarwal S, Sohal RS. Differential oxidative damage to mitochondrial proteins during aging. Mech Ageing Dev. 1995;85(1):55-63. https://doi. org/10.1016/0047-6374(95)01655-4.

28. Grune T, Shringarpure R, Sitte N, Davies K. Age-related changes in protein oxidation and proteolysis in mammalian cells. J Gerontol A Biol Sci Med Sci. 2001;56(11):B459-67. https://doi.org/10.1093/gerona/56.11.b459.

29. Mera K, Anraku M, Kitamura K, Nakajou K, Maruyama T, Otagiri M. The structure and function of oxidized albumin in hemodialysis patients: Its role in elevated oxidative stress via neutrophil burst. Biochem Biophys Res Commun. 2005;334(4):1322-8. https://doi.org/10.1016/j.bbrc.2005.07. 035.

30. Descamps-Latscha B, Witko-Sarsat V, Nguyen-Khoa T, Nguyen AT, Gausson V, Mothu N, London GM, et al. Advanced oxidation protein products as risk factors for atherosclerotic cardiovascular events in nondiabetic predialysis patients. Am J Kidney Dis. 2005;45(1):39-47. https://doi.org/10. 1053/j.ajkd.2004.09.011.

31. Liu SX, Hou FF, Guo ZJ, Nagai R, Zhang WR, Liu ZQ, et al. Advanced oxidation protein products accelerate atherosclerosis through promoting oxidative stress and inflammation. Arterioscler Thromb Vasc Biol. 2006;26(5):1156-62. https://doi.org/10.1161/01.ATV.0000214960.85469. 68.

32. Negm MS, Abdel Ghafar, MT, Elkhouly RA. Presepsin versus other inflammatory markers for the diagnosis of acute bacterial infections in chronic hemodialysis patients. Zagazig University Med J, 2020, https://doi.org/10. 21608/zumj.2020.38002.1912. [In Press]

33. Kaneda H, Taguchi J, Ogasawara K, Aizawa T, Ohno M. Increased level of advanced oxidation protein products in patients with coronary artery disease. Atherosclerosis. 2002;162(1):221-5. https://doi.org/10.1016/ s0021-9150(01)00706-7.

34. Korkmaz GG, Altınoglu E, Civelek S, Sozer V, Erdenen F, Tabak O, et al. The association of oxidative stress markers with conventional risk factors in the metabolic syndrome. Metabolism. 2013;62(6):828-35. https://doi.org/ 10.1016/j.metabol.2013.01.002.

35. Avinash SS, Anitha M, Rao GM, Sudha K, Shetty BV. Advanced oxidation protein products and total antioxidant activity in colorectal carcinoma. Indian J Physiol Pharmacol. 2009;53(4):370-4.

36. Kilic N, Yavuz Taslipinar M, Guney Y, Tekin E, Onuk E. An investigation into the serum thioredoxin, superoxide dismutase, malondialdehyde, and advanced oxidation protein products in patients with breast cancer. Ann Surg Oncol. 2014;21(13):4139-43. https://doi.org/10.1245/ s10434-014-3859-3.

37. Kosova F, Cetin B, Akinci M, Aslan S, Ari Z, Sepici A, et al. Advanced oxidation protein products, ferrous oxidation in xylenol orange, and malondialdehyde levels in thyroid cancer. Ann Surg Oncol. 2007;14(9):2616-20. https://doi.org/10.1245/s10434-007-9425-5.

38. Toricelli M, Pereira AAR, Souza Abrao G, Malerba HN, Maia J, Buck HS, et al. Mechanisms of neuroplasticity and brain degeneration: strategies for protection during the aging process. Neural Regen Res. 2021;16(1):58-67. https://doi.org/10.4103/1673-5374.286952.

39. Son JM, Lee C. Aging: All roads lead to mitochondria. Semin Cell Dev Biol. 2021 Doi: https://doi.org/10.1016/j.semcdb.2021.02.006. (Online ahead of print).

\section{Publisher's Note}

Springer Nature remains neutral with regard to jurisdictional claims in published maps and institutional affiliations.

Ready to submit your research? Choose BMC and benefit from

- fast, convenient online submission

- thorough peer review by experienced researchers in your field

- rapid publication on acceptance

- support for research data, including large and complex data types

- gold Open Access which fosters wider collaboration and increased citations

- maximum visibility for your research: over 100M website views per year

At BMC, research is always in progress.

Learn more biomedcentral.com/submissions 